\title{
The Relationship of Information Management and Organizational Agility: An Application on the Banking Sector
}

\section{Begüm Al ${ }^{1}$}

1 Asisstant Professor, Turkey Kent University,

Istanbul/Turkey

ORCID: $\underline{0000-0001-8839-4478}$

E-Mail:

begum.al@kent.edu.tr

Corresponding Author:

Begüm Al

January 2022

Volume:19

Issue: 45

DOI: $10.26466 / /$ opusjsr.1062874

Al, B. (2022). The relationship of information management and organizational agility: An application on the banking sector. OPUS- Journal of Society Research, 19(45), 158-170.

\begin{abstract}
The purpose of this research is to examine the relationship between information technology capability and organizational agility on the banking sector, which needs to adapt to environmental changes in the fastest way. The descriptive method was adopted in the research. The population of this research is all banking sector employees. A total of 170 banking sector employees participated in the research. Within the scope of the research, Organizational Agility Scale developed by Sharifi and Zhang (1999) and Knowledge Management Performance scale, which was brought to the literature by Lee, Lee and Kang (2004) but redeveloped by Çetinkaya (2011), were used. The obtained data were analyzed via SPSS. According to the analysis results, the dimension with the highest average among the sub-dimensions of the organizational agility scale was the "competency" dimension. "Responsiveness" is the subdimension with the lowest average. In the knowledge management scale, the sub-dimension with the highest average is "knowledge production"; the sub-dimension with the lowest average was "information sharing". The results of the regression analysis showed that the "knowledge sharing" sub-dimension of the knowledge management scale was over the "flexibility" sub-dimension and the "competency" subdimension of the organizational agility scale; on the "speed" sub-dimension of the organizational agility scale of the "information gathering" sub-dimension of the knowledge management scale and; Finally, the "knowledge production" sub-dimension has a statistically significant and positive effect on the organizational agility scale's "response" sub-dimension.
\end{abstract}

Key Words: Information, Information Management, Agility, Organizational Agility.

\section{Öz}

Bu araştırmanın amacl; bilgi teknolojileri yeteneği ve örgütsel çeviklik arasındaki ilişkiyi, çevresel değişikliklere en hızlı şekilde adaptasyonu gereken bankacılık sektörü üzerinde incelemektir. Araştırmada betimsel yöntem benimsenmiştir. Bu doğrultuda; araştırmanın evreni bankactlı sektörü çalışanlarının tamamıdır. Araştırmaya toplam 170 banka sektörü çalışanı katılmıştır. Araştırma kapsamında Sharifi ve Zhang (1999) tarafindan geliştirilen Örgütsel Çeviklik Ölçeği ve Lee, Lee ve Kang (2004) tarafindan yazına kazandırlan ve Çetinkaya (2011) tarafindan yeniden geliştirilen Bilgi Yönetimi Performansı ölçeği kullanılmıştır. Elde edilen veriler SPSS aracılığıyla analiz edilmiştir. Analiz sonuçlarına göre, örgütsel çeviklik ölçeği alt boyutları arasında en yüksek ortalamaya sahip olan boyut "yetkinlik" boyutudur. "Cevap verme" ise en düşük ortalamaya sahip alt boyut olarak belirlenmiştir. Bilgi yönetimi ölçeğinde ise en yüksek ortalamaya sahip olan alt boyut "bilgi üretimi"; en düşük ortalamaya sahip olan alt boyut ise "bilgi paylaşımı" olmuştur. Regresyon analizi sonuçlarına göre bilgi yönetimi ölçeği "bilgi paylaşımı" alt boyutunun örgütsel çeviklik ölçeği "esneklik" alt boyutu ve "yetkinlik" alt boyutu üzerinde; bilgi yönetimi ölçeği "bilgi toplama" alt boyutunun örgütsel çeviklik ölçeği "hız" alt boyutu üzerinde ve son olarak "bilgi üretimi" alt boyutunun örgütsel çeviklik ölçeği "cevap verme" alt boyutu üzerinde istatistiksel olarak anlamlı ve pozitif yönlü bir etkisi bulunmaktadır.

Anahtar Kelimeler: Bilgi, Bilgi Yönetimi, Çeviklik, Örgütsel Çeviklik. 


\section{Introduction}

Today, where the ability to adapt to change is almost mandatory, businesses are also constantly changing and transforming. It can be seen that companies that were pioneers in their field, in the previous periods were left behind by not being able to adapt to increasingly different conditions and not being able to compete with their competitors. It is more difficult for those who are in a leading position in technology companies to maintain their positions, and it seems possible that they will not be able to maintain this position in the future and perhaps may be deleted from the sector (Akkaya and Tabak, 2018, p. 186).

As recent examples; brands that were leaders in the mobile phone market in the past, such as Nokia and Ericsson, or companies that were pioneers in the photography market, such as Kodak, are far from other competitors such as Samsung, which cares about innovation today. These companies have lost their former positions as they could not supply in line with the demands and trends. When Apple and Samsung made phones smart and multifunctional tools, Ericsson and Nokia instead of adapting to innovations in this market; they predicted that push-button phones would continue to exist in the market and as a result lost their market share. A similar example applies to GPS (Global Positioning Systems) manufacturers. Highway maps, which have developed since the 90 's, started to be offered to the navigation market, then to the GPS and then to the customers free of charge, with smartphone applications, and thus, the independent GPS device manufacturers lost their market value by $85 \%$ in a period of 18 months (Downes and Nunes, 2014, p. 82).

In today's conditions, it is considered impossible for companies that cannot be involved in innovations with agility and cannot act in accordance with consumer demands. In terms of the continuity of its position in the market share and its competitiveness, an enterprise must produce appropriate solutions by taking into account the developments taking place inside and outside, and the new demands.

The concept of organizational agility, in other words, organizational agility gains great importance today (Ganguly, Nilchiani and Farr, 2009, p. 411). It is equally important to examine the concept of agility in the new competitive environment.

\section{Organizational Agility}

The concept of agility is a concept that creates a field of study in many subjects such as leadership, information technology and production. The concept of agility has also played a role in the derivation of concepts such as agile institution, agile system, agile business processes. The dictionary meaning of the word agility is stated as "the ability to think quickly and agile and at the same time wisely" (Basri and Zorlu, 2020, p. 148). It is possible with agility for businesses to take advantage of these opportunities by making a quick and pioneering evaluation of opportunities. Noticing the changes and developments that occur within or outside of the environment and creating solutions against these situations is seen as organizational agility (Doğan and Baloğlu, 2018, p. 102). In addition, the ability to quickly respond to different situations and turn these changes into opportunities is also described as agility (Braunscheidel and Suresh, 2009, p. 120).

The concept of organizational agility is expressed as agile production that occurs as a result of changes in an institution or sector and turning these changes into opportunities (Braunscheidel and Suresh, 2009, p. 120). On the other hand, Gunasekaran (1999) explains the concept of organizational agility as the ability to configure the resources, capabilities and strategies of the enterprises in the most effective and efficient way in order to quickly perceive and respond to the changes in the internal and external environment of the enterprises. This concept is also defined as the ability of a company to restructure, combine and create benefits to recognize sudden changes, dangers or opportunities in its environment and to respond quickly to them (Yang and Liu, 2012, p. 1024).

Goldman, Nagel and Preiss (1995) explain this concept as managing competition by following continuous and unpredictable developments and turning consumers' behaviors into their own 
advantages. In summary, the concept of organizational agility can be defined as the ability of businesses to be sensitive to changes in their environment, to gain competitive advantage in the market against competitors with new technologies, to quickly meet their demands and requests by positioning their customers in the center, and to increase the motivation and commitment levels of their employees (İnanır, 2020, p. 75).

\section{Characteristics of Agile Organizations}

For an organization to be agile, it is necessary to see a development or change early, evaluate and apply the data about it quickly and without error (Illeri and Soylu, 2010, p. 14). In other words, speed and flexibility are important in agile organizations.

The quick completion of a task and the ability to adapt to changes in the environment are also the result of agility. As a result, being agile means doing a job both quickly and flexibly (Sekman and Utku, 2009, p. 22). Quickness (being speed) means that businesses are fast while carrying out their activities, catching opportunities, keeping up with change and solving the problems encountered. For example, quick resolution of customer complaints, fast fulfillment of orders or quick approval from the manager for a purchase are all related to speed.

The ability to understand the developments and changes of the market and to adapt quickly to new situations is also explained as flexibility. For example, responding to the rapid change in market conditions at the same speed and providing the product requested by the customer quickly is a flexibility capability (Sekman and Utku, 2009, p. 22).

To be agile, a business can cooperate with the companies it competes with and may have to use other external resources (Dereli and Filiz, 2002, p. 143). Thus, planning and strategy become more important; developing and updated strategies make the company more dynamic. If a business has the goal of being agile in a competitive environment, it should be agile in more than one area instead of just a single business function (Wendler, 2016, p. 21). In this sense, organizational agility supports change in all processes (Armstrong, 2000, p. 576). Over time, the concept of organizational agility becomes a fixed part of organizational culture for businesses and provides an advantage to organizations (Karadal and Duman, 2020, p. 3).

\section{Dimensions of Organizational Agility}

There are four dimensions in organizational agility: "speed, flexibility, responsiveness and competency" (Zhang and Sharifi, 2000, p. 498). The ability of the organization to perform a task in the shortest possible time and without error refers to "speed". Sherehiy (2008) also explains this dimension with the ability to learn quickly.

The dimension of "responsiveness" explains the ability of businesses to notice and comprehend the developments in the environment, to predict, to respond reactively or proactively to them, and to adapt to change (İnanır, 2020, p. 74). This dimension is seen as the ability of enterprises to respond to the changes caused by national or international policies in the field of marketing, to changes in production models and competition criteria and to create more economical options due to technological developments (Zhang and Sharifi, 2000, p. 499). As an organization responds rapidly to changes in the environment, this capability is increasing. Determining a strategic vision, the ability to transfer innovations to the organizational culture can be counted among the ability to responsiveness.

"Flexibility" dimension is defined as the ability to regulate the structure, culture and ways of doing business of the enterprise against the developments that occur around it (Reed and Blunsdon, 1998, p. 459). Numerical, functional and financial flexibility are among the most used classifications of organizational flexibility in the literature. Numerical flexibility refers to the change in demands and outputs according to the number of employees and working hours of an enterprise; this change can result in positive results with the implementation of short-term and parttime flexible working styles in the enterprise. Financial flexibility relates to performanceoriented payment methods, profit-sharing planning and individual payments. Functional flexibility is defined as the flexibility of the job content and the flexibility of the change in the skills 
of the employees (Sherehiy, Karwowski and Layer, 2007, p. 446).

"Competency" dimension is defined as the ability to be competent. Issues such as working to ensure product and service quality, price policy, creating an appropriate technological infrastructure, qualification of personnel in terms of skills and knowledge and laying the groundwork for their development are evaluated within the scope of competency dimension (Zhang and Sharifi, 2000, p. 499).

Agile organizations have many advantages from advanced technology, restructuring, personnel training, opportunities, economic, social and cultural changes to sustainable competition (Sherehiy, 2008, p. 43). The concept of organizational agility, which is defined as the level of the ability to act quickly as an organization, contributes to living in uncertainty and has significant effects on performance (Sağır and Gönülölmez, 2019, p. 59).

In a report published by McKinsey in 2006, it is stated that increased agility in businesses means improved business processes, satisfied customers, employees with high job satisfaction, and therefore higher income (Karadal and Duman, 2020, p. 12).

\section{Information}

As a result of the research by Kuçuradi (1995), in which "information" and the object of information were examined, it is seen that the word "information" in some languages defines both the task of knowing and the outputs that result from this work. Kuçuradi (1995) draws attention to the fact that information, which is an activity specific to humans, includes multiple activities that are related to each other such as perception, understanding, thinking, interpretation, explanation, comparison, verification and evaluation.

As a concept information forms the basis of data and knowledge. It can easily be said that the definition of this concept, which is still popular today, has been sought and discussed since history. Çüçen (2001) stated that ancient Greek philosophers were working to make an explanation about information. In modern philosophy, epistemology (the theory of information) has become the main subject of philosophy and the possibilities, sources, dimensions, criteria and features of human knowledge have been examined in terms of epistemology. Philosophy of information, which generally examines what information is, where and how it emerges, investigates the connection between the knowing subject and the known object (Çüçen, 2001, p. 12).

Especially in Turkish sources, it is seen that both knowledge and information concepts are examined and explained only under the title of information concept. However, although knowledge and information are concepts that are directly related to each other, it is stated that they describe different concepts and point to different phenomena. Davenport and Prusak (2001) also state that these concepts are different from each other. According to them, information is not synonymous with data and knowledge. In this direction, the concept of knowledge has been discussed and defined from many different perspectives in the literature.

Barutçugil (2002) states that information is personalized knowledge that helps people to grasp the events taking place fully and accurately around them. According to Barutçugil (2002), facts such as thought, feeling, idea, foresight, experience and practice constitute information. Celep and Çetin (2003) emphasized the importance of treating information differently from the concepts of data and knowledge. It has been stated that the data are raw facts and when transferred, corrected and summarized, they gain value and turn into information (Celep and Çetin, 2003, p. 82). According to Davenport and Prusak (2001), information means a flexible combination of experience, value, goal-oriented information and expert opinion in a certain order, which puts a limit on the evaluation by combining new experience and knowledge.

It is stated that information manifests itself in the minds of those who know and is put into practice and in businesses, it usually emerges in daily activities, processes, practices and norms. Davenport and Prusak (2001) stated that information is not simple and emerges with the 
interaction of different phenomena with each other. Shapeless information is flexible and difficult to understand using words or logical terms when it comes to intuition. Within the framework of these data, the concept of information can be evaluated both as a process and as an accumulation.

\section{Information Management}

The two most important concepts in terms of management science are information and technology (Özer, 2013, p. 70). Information has a great value in businesses, at least as much as capital. For this reason, the age we live in today is the information age, the society is the information society and people are described as information workers (Atl1, 2014, p. 23).

Valuing information, knowing how to use information and being able to produce it are among the most important features to be considered an information society. And all these are realized through information technologies (Güçlü and Sotirofski, 2006, p. 353). Information management is a well-established discipline in both business and academic fields, as information is a power and an important resource on its own (Xie, Fang, Zeng and Huo, 2016, p. 1617).

Today, information is an easily accessible value depending on technology. However, it is a very difficult value in terms of protection. The information age, on the other hand, has gradually given rise to information competition, and this has affected not only societies but also businesses. Now, information has become an important production factor for businesses as much as capital and information management has also begun to be seen as a mental capital that can be controlled in the management of the enterprise (Selvi, 2012, p. 11). The clearest definition of information management is as follows: "To make the right decision, it is necessary to provide the right information in the right form, to the right person, at the right cost, at the right time, in the right place" (Tonta, 2004, p. 3).

Information management, defined by the American Center for Production and Quality, is characterized as systematic approaches to ensure that information reaches the right person at the right time to create a value (Buckman, 2004, p. 12). Liao and $\mathrm{Wu}$ (2010), on the other hand, while describing information management, mention three main processes as access to information, transformation of information and application of information. The process that covers the identification and analysis of the information required for the realization of organizational goals, and the planning and control of activities that develop information is called information management (İpçioğlu and Erdoğan, 2005, p. 91).

In another definition, information management is stated as a system that includes the stages of obtaining, processing, organizing and reusing recorded information (Kutvan and Savaş, 2011, p. 4). According to Barutçugil (2002), the management of information requires learning and sharing both individually and organizationally. According to Tonta (2004), the concept of information management is the practice of providing, controlling, publishing and using information about the effective operation and management of each entity. The concept of information is also used in the form of information generated inside or outside the organization, such as production data, personnel files, market research data (Tonta, 2004, p.3).

\section{Application of Information Management in Organizations}

Generating information is among the objectives of each organization. However, this can be considered as a very difficult task for organizations (Celep and Çetin, 2003, p.18). Information is a concept that has a very important effect on the capacity and effectiveness of organizations and is a prerequisite for technological production, which is necessary for the adaptation of organizations to innovations (Sawhney, 2001, p.260).

Amin and Cohendet (2004) divided information into five categories according to the learning method in the organization. This classification is explained below:

- Intelligent information: It consists of the talents of the employees and describes the learning potential.

- Embedded information: It represents practical thinking and learning by doing. 
This knowledge plays a role in the performances of experts and in training.

- Cultural information: It takes place in socialization processes, sharing, language and stories told in the organization.

- Established information: It is used in routine processes and technologies.

- Coded information: It is hidden in signs and symbols and is shown in books and manuals.

Information is not a once formed and fixed concept. Information can evolve in information production environments provided within the organization, or it can disappear when a job is concluded and not repeated. Again, information can be personalized by the person who revealed it and stored in data or processes for later use (Bell, 2001, p. 43).

The most important point in the success of organizations in the information economy is that organizations can add value that will raise themselves to higher levels each time (Barutçugil, 2002, p. 54). Organizations need to follow and implement some important stages in order to realize information management (Güçlü and Sotirofski, 2006, p. 352). The first of these stages is the creation of an information vision, considering the information capacities of employees and customers, and the preparation of an information management program in this direction. At this stage, it is very important to associate the information management program with the goals and objectives of the organization (Buckman, 2004, p. 22). The second stage is the creation of an information manager and a team responsible for the information management process (Awad and Ghaziri, 2004, p. 55). The next stage covers the control of accounts related to information assets. At this stage, there are points such as identifying the most important information, identifying the best practices in the sector, and identifying new research and development areas (Barutçugil, 2002, p. 55). After this step, standards, processes, responsibilities and technologies for the new information management structure should be determined (Öğüt, 2001, p. 121). As the last stage, the formation and continuity of organizational culture suitable for information management takes place (Tiwana, 2000, p. 54).

\section{Corporate Information Management Process}

Corporate information management is expressed as controlling all registered and unregistered information that occurs within the enterprise or obtained from outside, depending on a system (Barutçugil, 2002, p. 60). Information management is not just an information technology issue. Information management for businesses is an organizational culture issue. It is necessary to have a cultural structure that gives importance and value to information, appreciates information workers, believes that information grows as it is shared, and rewards those who use information effectively (Barutçugil, 2002, p. 62).

Especially in recent years, businesses have begun to realize the necessity of managing intangible or unregistered corporate information as well as the management of registered information (Odabaş, 2003, p. 358). In this direction, creating new information is not only about processing objective information mechanically, but also based on making use of employees' implicit and subjective insights, intuitions and ideals (Nonaka, 1999, p. 40). For businesses information management, besides being one of the necessary elements in order not to be left behind in the increasing global competition environment, has also become very critical to prevent unnecessary information production.

Having the right information at the right time is one of the important factors for businesses to increase their performance. However today, the amount of information obtained from both inside and outside of the enterprises has increased considerably, and as a result, managers are exposed to more information than necessary. The main problem here is that the information required for businesses cannot be separated from other information (Kalseth and Cummings, 2002, p. 165).

Information management process consists of a wide variety of elements to ensure the continuity of corporate activities. Information technologies, which take an active role in corporate communication and their effective use, are the 
most important among these elements. Through various software and factors such as wireless communication, it is possible for all employees to manage all the information of the enterprise on a single system (Barutçugil, 2002, p. 64).

\section{Methodology}

In this study, the descriptive method, whose purpose is to reveal the current state of the phenomenon to be investigated, was used. The universe of the research is all banking sector employees working in Turkey. A total of 186.654 people work in deposit banks and development and investment banks in Turkey. Since this number was quite high for research, a sample was used. For sample calculation, the sample calculation tool available on the internet was used. This calculation tool can be accessed from the following link: https://www.calculator.net/sample-size-

calculator.html. When the calculations were made with 95 percent reliability and 5 percent margin of error, the number of samples to be examined within the scope of the research was determined as 383. In this context, 383 scale forms were sent to bank employees via e-mail.

Banking sector employees were identified through the LinkedIn social platform, and scale forms were sent to the identified employees using public e-mail addresses available on the same platform. A total of 170 scales were evaluated within the scope of the study since some of the scales were not filled in completely. The data collection application was carried out between September 1, 2019 and November 1, 2019.

The data collection tool used within the scope of the research consists of 3 parts. In the first part, the "Organizational Agility Scale" developed by Sharifi and Zhang (1999) was used. This scale consists of 20 questions and 4 dimensions (competency, flexibility, responsiveness, speed). Responses were expected in a 5-point Likert scale (1=Never, 2=Rarely, 3=Sometimes, 4=Often, $5=$ Always).

In the second part of the questionnaire, the "Information Management Performance" scale, which was brought to the literature by Lee, Lee and Kang (2004) and redeveloped by Çetinkaya
(2011), was used. This scale consists of 23 questions and 4 sub-dimensions (information production, information gathering, information sharing and information storing). Responses were expected in a 5-point Likert scale ( $1=$ Strongly Disagree, 2=Disagree, $3=$ Neither Agree or Disagree, 4=Agree, $5=$ Strongly Agree).

In the last part of the questionnaire, the participants were asked to fill in the demographic questionnaire. In this form, participants were asked about their gender, age, marital status and educational status.

SPSS was used for the analysis. First of all, the demographic characteristics of the participants were determined through frequency analysis. Afterwards, the results of the factor and reliability analysis of the scales are given. Following this, all descriptive statistics regarding the scales and their sub-dimensions are presented. Finally, the relationships between information management and organizational agility were revealed by using correlation and regression analysis.

Before moving on to the findings part of the study, demographic characteristics of the participants and reliability analyzes of the scales used were given. First, the demographic characteristics of the participants are presented in the table below:

Table 1. Demographic characteristics of the participants

\begin{tabular}{lll}
\hline \multirow{2}{*}{ Gender } & Male & Percentage (\%) \\
\cline { 2 - 3 } & Female & 56 \\
\hline Age & $18-25$ & 84 \\
\cline { 2 - 3 } & $26-35$ & 38 \\
\cline { 2 - 3 } & $36-45$ & 35 \\
\hline Marital status & Married & 66 \\
\cline { 2 - 3 } & Single & 34 \\
\hline Education status & High school & 8 \\
\cline { 2 - 3 } & University & 64 \\
\cline { 2 - 3 } & Master degree & 28 \\
\hline Working status & Full time & 85 \\
\cline { 2 - 3 } & Part time & 15 \\
\hline
\end{tabular}

According to the results of the analysis, $56 \%$ of the participants are male and $44 \%$ are female. Most of the participants are between the ages of 26-45. Many of the participants $(66 \%)$ are married individuals, and the majority (64\%) have university degree. $85 \%$ of the participants work full-time in the bank and 15\% work part-time.

The factors and reliability results of the scales used in the research, based on the findings 
obtained within the scope of this research, are given below:

Table 2. Results of organizational agility scale factor and reliability analysis

\begin{tabular}{|c|c|c|c|}
\hline Factor name & Factor items & Factor weights & $\begin{array}{l}\text { Reliability (Cronbach } \\
\text { Alpha) }\end{array}$ \\
\hline \multirow[t]{8}{*}{ Competency } & OA 1 & ,709 & \multirow{8}{*}{.856} \\
\hline & OA 2 & ,780 & \\
\hline & $\overline{\mathrm{OA} 3}$ & ,797 & \\
\hline & $\overline{\mathrm{OA}} 4$ & 699 & \\
\hline & OA 5 & ,735 & \\
\hline & OA 6 & ,722 & \\
\hline & OA 7 & 854 & \\
\hline & $\overline{\mathrm{OA}} 8$ & ,786 & \\
\hline \multirow[t]{3}{*}{ Flexibility } & OA 9 & ,731 & \multirow{3}{*}{879} \\
\hline & OA 10 & ,793 & \\
\hline & OA 11 & 844 & \\
\hline \multirow[t]{3}{*}{ Responsiveness } & OA 12 & 822 & \multirow{3}{*}{.758} \\
\hline & OA 13 & 865 & \\
\hline & $\overline{\mathrm{OA} 14}$ & 825 & \\
\hline \multirow[t]{3}{*}{ Speed } & OA 15 & ,734 & \multirow{3}{*}{.880} \\
\hline & $\overline{\mathrm{OA} 16}$ & ,793 & \\
\hline & $\overline{\mathrm{OA}} 17$ & 835 & \\
\hline \multicolumn{3}{|l|}{ Total organization } & .898 \\
\hline
\end{tabular}

OA: Organizational Agility

As a result of the factor analysis, a total of 4 subdimensions of the organizational agility scale were determined. The reliability coefficient of the total scale was determined as 0.898 . This indicates that the scale is highly reliable. The reliability coefficients of the sub-dimensions of the scale also vary between 0.758 and 0.880 .

Table 3. Results of information management scale factor and reliability analysis

\begin{tabular}{|c|c|c|c|}
\hline Factor name & $\begin{array}{l}\text { Factor } \\
\text { items }\end{array}$ & Factor weights & $\begin{array}{l}\text { Reliability } \\
\text { (Cronbach Alpha) }\end{array}$ \\
\hline \multirow{7}{*}{$\begin{array}{l}\text { Information } \\
\text { production }\end{array}$} & IM 1 & ,730 & \multirow{7}{*}{.745} \\
\hline & IM 2 & ,704 & \\
\hline & IM3 & 835 & \\
\hline & IM 4 & 890 & \\
\hline & IM 5 & 832 & \\
\hline & IM 6 & 869 & \\
\hline & IM 7 & ,786 & \\
\hline \multirow[t]{7}{*}{ Information gathering } & IM 8 & 800 & \multirow{7}{*}{.895} \\
\hline & IM 9 & ,774 & \\
\hline & IM 10 & ,755 & \\
\hline & IM 11 & 858 & \\
\hline & IM 12 & 899 & \\
\hline & IM 13 & ,744 & \\
\hline & IM 14 & ,752 & \\
\hline \multirow[t]{5}{*}{ Information sharing } & IM 15 & 795 & \multirow{5}{*}{.851} \\
\hline & IM 16 & 658 & \\
\hline & IM 17 & ,763 & \\
\hline & IM 18 & 832 & \\
\hline & IM 19 & 838 & \\
\hline \multirow{4}{*}{ Information storing } & IM 20 & 723 & \multirow{4}{*}{.812} \\
\hline & IM 21 & 615 & \\
\hline & IM 22 & 612 & \\
\hline & IM 23 & 673 & \\
\hline \multicolumn{3}{|c|}{ Total information management } & .899 \\
\hline
\end{tabular}

As a result of the factor analysis applied to the knowledge management scale, it was determined that the scale had a total of 4 sub-dimensions. The reliability coefficient of the total scale is 0.899 . This value means that the scale is highly reliable. The reliability coefficients of the sub-dimensions of the scale also vary between 0.745 and 0.895 .

\section{Results}

\section{Table 4. Descriptive statistics}

\begin{tabular}{lllllll}
\hline & & $\mathbf{N}$ & Min. & Max. & Average & $\begin{array}{l}\text { Std. } \\
\text { deviation }\end{array}$ \\
\hline $\begin{array}{l}\text { Organizational } \\
\text { agility }\end{array}$ & Competency & 170 & 1,00 & 5,00 & 4,18 &, 9763 \\
\cline { 2 - 7 } & Flexibility & 170 & 1,00 & 5,00 & 2,75 & 1,2455 \\
\cline { 2 - 7 } & Responsiveness & 170 & 1,00 & 5,00 & 2,90 & 1,3456 \\
\cline { 2 - 7 } & $\begin{array}{l}\text { Speed } \\
\text { Organizational } \\
\text { agility - total }\end{array}$ & 170 & 1,00 & 5,00 & 3,20 &, 5677 \\
\hline $\begin{array}{l}\text { Information } \\
\text { management }\end{array}$ & $\begin{array}{l}\text { Information } \\
\text { production }\end{array}$ & 170 & 1,00 & 5,00 & 3,26 & 4,4567 \\
& $\begin{array}{l}\text { Information } \\
\text { gathering }\end{array}$ & 170 & 1,00 & 5,00 & 4,10 &, 2467 \\
& $\begin{array}{l}\text { Information } \\
\text { sharing }\end{array}$ & 170 & 1,00 & 5,00 & 2,84 & 1,456 \\
\hline & $\begin{array}{l}\text { Information } \\
\text { storing }\end{array}$ & 170 & 1,00 & 5,00 & 3,94 &, 4675 \\
\hline $\begin{array}{lllllll}\text { Information } \\
\text { management - } \\
\text { total }\end{array}$ & 170 & 1,00 & 5,00 & 3,78 &, 4578 \\
\hline
\end{tabular}

According to the results of the analysis, the dimension with the highest average among the sub-dimensions of the organizational agility scale is the "competency" dimension. "Responsiveness" is the sub-dimension with the lowest mean. In the information management scale, the sub-dimension with the highest average is "information production"; the sub-dimension with the lowest average was "information sharing".

Table 5. Correlation analysis results

\begin{tabular}{|c|c|c|c|c|}
\hline & $\begin{array}{l}\text { Comp } \\
\text { ncy }\end{array}$ & $\begin{array}{l}\text { eFlexibili } \\
\text { ty }\end{array}$ & $\begin{array}{l}\text { Responsiven } \\
\text { ess }\end{array}$ & $\begin{array}{l}\text { Organization } \\
\text { al agility - } \\
\text { Speedtotal } \\
\end{array}$ \\
\hline $\begin{array}{l}\text { Information Pearson } \\
\text { production }(\mathrm{r})\end{array}$ & ,743 & ,355 &, $489^{* *}$ & 432, 467, \\
\hline Sig. (p) & ,090 & ,145 & , 000 & , 090 \\
\hline $\begin{array}{l}\text { Information Pearson } \\
\text { gathering }(\mathrm{r})\end{array}$ & ,467 & ,479 & ,463 & , $748^{* *}, 340$ \\
\hline Sig. (p) & ,101 & ,467 & ,234 & , 358 \\
\hline $\begin{array}{l}\text { Information Pearson } \\
\text { sharing } \quad(\mathrm{r})\end{array}$ &, $284^{* *}$ &, $564^{* *}$ & ,899 & 332, 442, \\
\hline Sig. (p) & , 010 & ,004 &, 141 & ,230 \\
\hline $\begin{array}{l}\text { Information Pearson } \\
\text { storing } \quad(r)\end{array}$ & ,468 & ,460 & ,224 & 324, 131, \\
\hline Sig. (p) & ,096 & 248 &, 422 & $, 139,221$ \\
\hline $\begin{array}{l}\text { Information Pearson } \\
\text { managemen }(\underline{r})\end{array}$ & 240 & 672 & 321 & 113, 331, \\
\hline Sig. (p) &, 357 & ,343 &, 144 & ,334 \\
\hline
\end{tabular}


According to the correlation analysis results, there is a positive and statistically significant relationship between the information management scale sub-dimension "information sharing" and the organizational agility scale "competency" subdimension $(r=.284, p=.010<0.05)$. There is also a positive and statistically significant relationship between the information management scale subdimension "information sharing" and the organizational agility scale "flexibility" subdimension $(r=.564, p=.004<0.05)$.

It is seen that there is a positive and statistically significant relationship between the subdimensions of the information management scale "information production" and the "responsiveness" sub-dimension of the organizational agility scale $(\mathrm{r}=.489, \mathrm{p}=.000<0.05)$. Finally, there is also a positive and statistically significant relationship between the "information gathering" subdimension of the information management scale and the "speed" sub-dimension of the organizational agility scale $(r=.748, \mathrm{p}=.007<0.05)$.

\section{Table 6. Regression analysis results}

\begin{tabular}{llll}
\hline & R2 & B & Sig $(p)$ \\
\hline Flexibility $\leftarrow$ Information sharing & .145 & .473 & .030 \\
\hline Competency $\leftarrow$ Information sharing & .456 & .345 & .001 \\
\hline Speed $\leftarrow$ Information gathering & .343 & .350 & .005 \\
\hline Responsiveness $\leftarrow$ Information production & .332 & .678 & .008 \\
\hline
\end{tabular}

According to the results of the regression analysis, the "information sharing" sub-dimension of the information management scale has a statistically significant positive effect on the "flexibility" sub-dimension of the organizational agility scale $(\beta=.473, p=.030<0.05)$. Again, the "information sharing" sub-dimension of the information management scale has a statistically significant positive effect on the "competency" subdimension of the organizational agility scale $(\beta=.345, p=.001<0.05)$. At the same time, the "information gathering" sub-dimension of the information management scale has a statistically significant and positive effect on the "speed" subdimension of the organizational agility scale $(\beta=.350, \quad \mathrm{p}=.005<0.05)$. The "information production" sub-dimension of the information management scale has a statistically significant and positive effect on the "responsiveness" sub- dimension of the organizational agility scale $(\beta=.678, \mathrm{p}=.008<0.05)$.

\section{Conclusion}

The aim of this research is to examine the relationship between information technology capability and organizational agility on the banking sector. A total of 170 questionnaires were evaluated within the scope of the research since some of the questionnaires were not fully filled. The data obtained within the scope of the research were analyzed through SPSS.

According to the results of the analysis, the dimension with the highest average among the sub-dimensions of the organizational agility scale was the dimension of "competency". "Responsiveness" is the sub-dimension with the lowest mean. As mentioned before, the competency dimension is the ability of an enterprise to be efficient, effective and sufficient while achieving its goals. In this sense, issues such as creating a strategic vision, working to ensure product and service quality, a reasonable price policy, creating an appropriate technological infrastructure, and the competence of the personnel in terms of skills and knowledge are evaluated within the scope of competency (Zhang and Sharifi, 2000, p. 499). Responsiveness describes the ability of businesses to recognize and grasp the developments in the environment, to anticipate, to respond reactively or proactively to them, and to face change without being harmed (Inanır, 2020, p. 79). This dimension is seen as the ability of enterprises to respond to changes caused by national or international policies in the field of marketing, to changes in production models and competition criteria, to create more economical options due to technological developments, and to respond to cultural and political differences that arise outside the enterprise (Zhang and Sharifi, 2000, p. 499). It can be said that the banking sector in Turkey has sufficient and competent personnel and infrastructure but is weak against environmental changes and effects. Competence is of course an important factor, but companies that cannot keep up with environmental changes have a very low chance of survival. In this sense, banks should follow the changes in their operating 
environment well and adapt to the changes quickly.

In the information management scale, the subdimension with the highest average is "information production; the sub-dimension with the lowest average was "information sharing". At this point, it can be said that information production is related to competence. In this sense, it can be said that banks in Turkey are quite sufficient in terms of producing information but lacking in sharing this information. Information sharing is also important at the point of increasing the learning competence of an organization, and learning is one of the main points of being an agile organization. At this point, there are many steps that can be taken by organizations. For example, by developing a good corporate communication strategy, intra-organizational communication can be activated. Again, within the scope of this strategy, the communication between the employees of the organization will be improved and the obstacles to being an agile organization will be removed. With the trainings to be offered, the information transfer of the employees to each other will also be increased.

When the relations between information management and organizational agility are examined, a positive and statistically significant relationship has emerged between the information management scale sub-dimension "information sharing" and the organizational agility scale "competency" sub-dimension and the "flexibility" sub-dimension. In other words, as information sharing increases, the level of competency and flexibility also increases. Employees' sharing their current knowledge with other employees reduces the need for additional in-house training and enables the organization to keep up with changing and developing conditions faster and more effectively. The organization becomes more flexible and competent, and time is also saved.

Another finding is that there is a positive and statistically significant relationship between the "information production" sub-dimensions of the information management scale and the "responsiveness" sub-dimension of the organizational agility scale. In other words, the faster the organization produces solutions to the emerging problems, the faster it will be able to respond to the variability and needs.

Finally, a positive and statistically significant relationship was found between the "information gathering" sub-dimension of the information management scale and the "speed" sub-dimension of the organizational agility scale. The information that emerges as the data are raw facts and gains value and turns into information when transferred, corrected, summarized (Celep and Çetin, 2003, p. $82)$, will also increase the speed of organizational agility. Because organizations will be able to respond quickly and effectively to the extent that they can understand their competitors, sectors or customers.

According to the results of the regression analysis, the "information sharing" sub-dimension of the information management scale has a statistically significant positive effect on the "flexibility" sub-dimension and the "competency" sub-dimension of the organizational agility scale. At the same time, the "information gathering" subdimension of the information management scale has a statistically significant and positive effect on the "speed" sub-dimension of the organizational agility scale. Finally, it was concluded that the "information production" sub-dimension of the information management scale has a statistically significant and positive effect on the organizational agility scale's "responsiveness" subdimension.

The results revealed that there are statistically significant relationships between information management and organizational agility. It is an undeniable fact that if information management is applied correctly, businesses increase their productivity. With information management, businesses can be in a more creative position compared to their competitors in an increasingly competitive environment, and they can optimize the interaction between product development and marketing activities. In addition, as a result of the effective use of information management, businesses can provide continuity and profit increase. The communication between all employees of the enterprise also develops with information management and the participation of employees in business management is ensured. 
Additionally, within the scope of this research, it was concluded that information management also positively affects organizational agility. However, to make these contributions, businesses must first have a healthy organizational culture, strong management expertise and an advanced information technology infrastructure.

There are also various limitations within the scope of this research. The first of these limitations is related to the number of banking sector employees participating in the research. 170 bank employees participated in the research. This number is quite high and may lead to various discussions about the reliability of the evaluation of the results. Although the number is high, it is assumed that the participants filled the questionnaires with all honesty and that all information is realistic and accurate.

The results of the reliability analysis also support this situation. Another limitation is related to the fact that the data were evaluated only by qualitative analysis. In this sense, within the scope of this research, human feelings and thoughts were not included verbally and statistical results were tried to be obtained. Qualitative research methods, in which emotions and thoughts are used intensively, are offered as suggestions for other researches to be applied after this research.

\section{References}

Akkaya, B., \& Tabak, A. (2018). Örgütsel çeviklik ölçeğinin Türkçeye uyarlanması: Geçerlik ve güvenirlik çalışması. İş ve Insan Dergisi, 5(2), 185-206.

Amin, A., \& Cohendet, P. (2004). Architectures of knowledge. Oxford: Oxford University Press.

Armstrong, M. (2000). The name has changed but has the game remained the same?. Employee Relations, 22(6), 576-593.

Atlı, D. (2014). Bilgi çağında işletmeler açısından bilgi yönetimi ve stratejik önemi. XVI. Akademik Bilişim Konferansı Bildirileri, 5-7 Şubat, Mersin Üniversitesi, Mersin.

Awad, E., \& Ghaziri, H. (2004). Knowledge management. New Jersey: Prentice Hall Publishing.

Banihashemi, S.A., \& Dahmardeh, N. (2010). Organizational agility and agile manufacturing. European Journal of Economics,
Finance and Administrative Sciences, 27, 178184.

Barutçugil, İ. (2002). Bilgi yönetimi. İstanbul: Kariyer Yayıncılık İletişim.

Basri, S., \& Zorlu, K. (2020). Örgüt kültürü algısının örgütsel çeviklik üzerindeki etkisinin incelenmesi. Sosyal Ekonomik Araştırmalar Dergisi, 20(39), 147-164.

Bell, H. (2001). Measuring and managing knowledge. Singapore: McGraw-Hill.

Braunscheidel, M.J., \& Suresh, N. C. (2009). The organizational antecedents of a firm's supply chain agility for risk mitigation and response. Journal of operations Management, 27(2), 119140.

Buckman, R. (2004). Building a knowledge - driven organization. New York: McGraw-Hill.

Celep, C., \& Çetin, B. (2003). Bilgi yönetimi. Ankara: Anı Yayınları.

Çüçen, A.K. (2001). Bilgi felsefesi. Bursa: Asa Kitabevi Davenport, T.H., \& Prusak. L. (2001). İş dünyasında bilgi yönetimi: kuruluşlar ellerindeki bilgiyi nasıl yönetirler. (Çev. Günhan Günay). İstanbul: Rota Yayınları.

Dereli, T., \& Filiz, I. H. (2002). A design for manufacturing system for elimination of critical feature interactions on prismatic parts. Journal of Engineering Design, 13(2), 141157.

Doğan, O., \& Baloğlu, N. (2018). Örgütsel çeviklik ve bazı eğitim kurumlarındaki yansımaları. Ĕ̆itim Yönetimi Araştırmaları, p.100-109.

Downes, L., \& Nunes, P. (2014). Big bang disruption: Strategy in the age of devastating innovation. New York: Portfolio/Penguin.

Ganguly, A., Nilchiani, R., \& Farr, J.V. (2009). Evaluating agility in corporate enterprises. International Journal of Production Economics, 118(2), 410-423.

Goldman, S.L., Nagel, R.N., \& Preiss, K. (1995). Agile competitors and virtual organizations: Strategies for enriching the customer. New York.

Gunasekaran, A. (1999). Agile manufacturing: A framework for research and development. International Journal of Production Economics, 62(1), 87-105.

Güçlü, N., \& Sotirofski, K. (2006). Bilgi yönetimi. Türk Ĕ̆itim Bilimleri Dergisi, 4(4), 351-371.

İleri, Y.Y., \& Soylu, Y. (2010). Bir rekabet üstünlüğü aracı olarak çeviklik kavramı ve örgüt yapısına olası etkiler. Selçuk Üniversitesi 
Sosyal Bilimler Meslek Yüksekokulu Dergisi, 13(1-2), 13-28.

İnanır, A. (2020). Örgütsel çeviklik. Sağır, M. (Ed.). Modern İşletmecilikte Yönetsel Konular, in (p.71-80). Konya: Eğitim Yayınevi.

İpçioğlu, İ., \& Erdoğan, Z. (2005). İşletme stratejisinin belirlenmesinde bilgi yönetimi altyapısının analizi. Anadolu Üniversitesi Sosyal Bilimler Dergisi, 5(2), 89-111.

Kalseth, K., \& Cummings, S. (2002). Knowledge management: development strategy or business strategy?. Information Development, 17(3), 163-171.

Karadal, H., \& Duman, N. (2020). Teknogirişimciliğin ekosistemi olan teknoparklarda örgütsel çevikliğin etkisi üzerine bir değerlendirme. Karadal, H., Halis, M., Mert, G. (Eds). Girişimcilik \& Liderlik: Güncel Gelişmeler içinde (s.1-15). İstanbul: Akademi Titiz Yayınları.

Kuçuradi, İ. (1995). Knowledge and its object. Kuçuradi, İ. and Cohen, R.S. (Ed.). The concept of knowledge: The Ankara Seminar içinde (s.97102). Dordrecht: Kluwer.

Kutvan, A.B., \& Savaş, T. (2011). Bilgi yönetimi, bilginin toplumsallaştırılması ve bir toplumsal bellek projesi olarak "index periyodik yayınlar veritabanı" üzerine bir inceleme. Academic Journal of Information Technology, 2(4), 1-17.

Liao, S., Wu, C. (2010). System perspective of knowledge management, organizational learning, and organizational innovation. Expert Systems with Applications, 37, 10961103.

Nonaka, I. (1999). Bilgi Yaratan Şirket. Bilgi Yönetimi içinde (s.29-50). Ankara: Türkiye Metal Sanayicileri Sendikası.

Odabaş, H. (2003). Kurumsal bilgi yönetimi. Türk Kütüphaneciliği, 17(4), 357-368.

Öğüt, A. (2001). Bilgi çağında yönetim. Ankara: Nobel Yayıncilik.

Özer, M.A. (2013). Bilgi yönetimi aracılığıyla bilginin etkin kullanımı. Mukaddime, 7, 69-99.

Reed, K., \& Blunsdon, B. (1998). Organizational flexibility in Australia. International Journal of Human Resource Management, 9(3), 457-477.

Sağır, M., \& Gönülölmez, A. (2019). Yapısal sermaye ve insan sermayesinin işletme performansına etkileri: örgütsel çevikliğin aracılık rolü.
Mehmet Akif Ersoy Üniversitesi Sosyal Bilimler Enstitüsü Dergisi, 11(27), 58-77.

Sawhney, M. (2001). Beyond customer knowledge management: customers as knowledge cocreators. Knowledge Management and Virtual Organizations içinde (s.258-281). New York: Idea Group Publishing.

Sekman, M., \& Utku, A. (2009). Çevik şirketler: Kurumsal ataleti yenmek. 6. Baskı. İstanbul: Alfa Yayınları.

Selvi, Ö. (2012). Bilgi toplumu, bilgi yönetimi ve halkla ilişkiler. Gümüşhane Üniversitesi İletişim Fakültesi Elektronik Dergisi, 3, 191-214.

Sherehiy, B. (2008). Relationships between agility strategy, work organization and workforce agility. University of Louisville.

Sherehiy, B., Karwowski, W., \& Layer, J.K. (2007). A review of enterprise agility: concepts, frameworks and attributes. International Journal of Industrial Ergonomics, 37, 445-460.

Tiwana, A. (2000). The Knowledge Management Toolkit. Upper Saddle River: Prentice Hall.

Tonta, Y. (2004). Bilgi yönetiminin kavramsal tanımı ve uygulama alanları. Kütüphaneciliğin Destanı Sempozyumu, 21-24 Ekim 2004, Ankara.

Wendler, R. (2016). Dimensions of organizational agility in the software and it service industry: insights from an empirical investigation. Communications of the Association for Information Systems, 39(1), 21.

Xie, X., Fang, L., Zeng, S., \& Huo, J. (2016). How does knowledge inertia affect firms product innovation?. Journal of Business Research, 69, 1615-1620.

Yang, C., Liu, \& H.M. (2012). Boosting firm performance via enterprise agility and network structure. Management Decision, 50(6), 1022-1044.

Zhang, Z., \& Sharifi, H. (2000). A methodology for achieving agility in manufacturing organizations. International Journal of Operations and Production Management, 20(4), 496-512. 